\title{
THERMAL, MINERALOGICAL AND CHEMICAL STUDIES OF THE MORTARS USED IN THE CATHEDRAL OF PAMPLONA (SPAIN)
}

\section{J.I. Alvarez, I. Navarro, P.J. García Casado}

Department of Chemistry and Soil Science, Faculty of Science, University of Navarra, 31.080, Pamplona (Spain)

$\mathrm{N}^{0}$ of pages: 15

$\mathrm{N}^{\mathrm{o}}$ of tables: 8

$\mathrm{N}^{\mathrm{o}}$ of figures: 11

Keywords: Ancient mortars, Thermal analysis, Chemical studies, X-ray diffraction, Raw materials.

Please, send all correspondence to:

Dr. José I. Alvarez-Galindo

Dpto. de Química y Edafología

Fac. de Ciencias

Universidad de Navarra

$\mathrm{C} /$ Irunlarrea s/n

31.080 Pamplona (Navarra)

Spain

Phone: 34948425600

Fax: 34948425649

E-mail: jalvarez@unav.es 


\title{
THERMAL, MINERALOGICAL AND CHEMICAL STUDIES OF THE MORTARS USED IN THE CATHEDRAL OF PAMPLONA (SPAIN)
}

\author{
J.I. Alvarez, I. Navarro, P.J. García Casado \\ Department of Chemistry and Soil Science, Faculty of Science, University of Navarra, \\ 31.080, Pamplona (Spain)
}

\begin{abstract}
Different ancient mortar samples of Pamplona Cathedral have been analyzed to characterize their binder and aggregate fractions. A complete characterization has been carried out including chemical (complete macrochemical analysis, analysis of the soluble fraction in hot $\mathrm{HCl}$ (1:5) and of the insoluble residue, trace elements and soluble salts, using traditional chemical procedures, ion chromatography and spectrophotometry techniques), mineralogical (structural characterization, granulometric studies and X-ray diffraction) and thermal studies (simultaneous DTA and TG analysis). A lime binder with a silica aggregate have been established. The approximate original compositions of the classes of mortars have been determined using the TG results. A good agreement with the other characterization techniques has been showed by the thermoanalytical techniques. An incomplete carbonation in a sample has been discovered by the thermal analysis.
\end{abstract}

Keywords: Ancient mortars, Thermal analysis, Chemical studies, X-ray diffraction, Raw materials. 


\section{Introduction and objetives}

In some previous papers the importance of characterising the binding materials and mortars used by ancient builders has been highlighted [1-4]. In this study different samples were taken from the mortars of walls and domes from the inside of the cathedral of Pamplona (1415-1512). A further group of samples taken from the foundations of the old Romanesque cathedral, destroyed in 1390, are also taken into consideration. The seven zones classified with different types of mortar have already been established in a previous study [5] using a method proposed which consisted of:

Grouping the mortars. Analysis of all the samples.

1. Examination

- macroscopic examination with the naked eye with the help of a magnifying glass.

- microscopic examination using microphotography with magnification $\times 65$.

2. X-ray diffraction: in order to establish the mineralogical phases present.

3. Rapid approximate chemical analysis with hot $\mathrm{HCl}(1: 5)$ volume ratio (2 M) which has proved to be the most appropriate for attack [6]. Determination of the insoluble residue, the calcium carbonate fraction calculated by calcimetry and soluble fraction by difference to 100 .

4. Classification of the types of mortars taking into consideration the aforementioned criteria and using as well the relationship between insoluble residue/soluble fraction

In this study the $2^{\text {nd }}$ part of the proposed methodology (complete characterization of the mortars) has been carried out. The characteristics of the previously determined types of mortars and of their component materials are presented. The accordance among different analytical techniques is also studied.

\section{Experimental}


The sampling procedure for mortars has been carried out taking a part of the mortars with a chisel and throwing away the external portion of the joints, with the aim of obtaining non-altered material. Figure 1 shows the sampling areas with a different type of mortar, just as there has been indicated.

A representative sample of each different zone has been selected in order to apply the complete characterization. The criteria followed have been: the state of aggregation and structure, the available quantity and the representativity on the set.

After, the aforementioned complete characterization has been carried out. This one includes:

1. Chemical study

\subsection{Chemical composition:}

1.1.1. Chemical analysis of the majority components. This analysis has been carried out by attack with a sodium carbonate - borax alkaline flux.

1.1.2. Chemical analysis of the soluble fraction and the insoluble residue resulting from the attack of the mortar with hot $\mathrm{HCl}(1: 5)$.

The sample ground in an agate mortar was dried in a heater until constant weight was achieved and then $1 \mathrm{~g}$ of sample was taken for its subsequent analysis. A titration with EDTA (using murexide and eriochrome black $\mathrm{T}$ as indicators) has been used for the analysis of calcium and magnesium in the soluble fraction. The contents of soluble silica, Fe and Al have been determined by atomic emission spectroscopy with inductively coupled plasma (ICP). When the amounts of $\mathrm{Fe}_{2} \mathrm{O}_{3}$ and $\mathrm{Al}_{2} \mathrm{O}_{3}$ were higher than $1 \%$, the determinations were carried out by titrations using barium diphenylaminosulphonate and ditizone as indicators. Sodium and potassium have been determined by flame emission atomic spectroscopy. The contents of elements after an alkaline fusion of the samples were determined by traditional chemical methods. 
1.2. Trace elements: the chemical nature of the trace elements and their relative concentrations have been determined using the ICP technique, after an alkaline attack of the sample. Detection limits were 2,7 ng/g for cadmium, 6,1 ng/g for chromium, 5,4 ng/g for copper, 1,4 ng/g for manganese, 7,9 ng/g for molybdenum, $10 \mathrm{ng} / \mathrm{g}$ for nickel, 42,0 ng/g for lead and 1,8 ng/g for zinc.

1.3. Soluble salts: conductivity and concentrations of anions have been calculated using an ion chromatograph, after an extraction with distilled water. The instrumental detection limits were $0,084 \mu \mathrm{g} / \mathrm{g}$ for chloride, $0,475 \mu \mathrm{g} / \mathrm{g}$ for nitrate and $0,330 \mu \mathrm{g} / \mathrm{g}$ for sulphate.

2. Mineralogical study.

2.1. Mineralogical aggregate composition: the mineralogical phases contained in the aggregate were determined by X-ray diffraction.

2.2. Aggregate granulometric fractions: the grading of the aggregate was obtained after dissolution of the binding material with $\mathrm{HCl} \mathrm{1:1} \mathrm{and} \mathrm{sieving} \mathrm{through} \mathrm{a} \mathrm{tower} \mathrm{of}$ sieves.

3. Thermal studies: the differential thermal and thermogravimetric analysis were carried out using a simultaneous DTA-TGA Stanton Redcroft STA-780 thermoanalyser, using Pt crucibles, at $10^{\circ} \mathrm{C} \cdot \mathrm{min}^{-1}$ heating rate, under $50 \mathrm{~mL} \cdot \mathrm{min}^{-1}$ gas flow of air.

\section{Results and Discussion}

The previous results of the X-ray diffraction analyses are showed that in the mortars of Cathedral of Pamplona, calcite is the main component [7]. The other mineralogical phase presents in a large quantity was $\alpha-\mathrm{SiO}_{2}$. Several samples had complex silicates in their composition, although in small amounts. Gypsum phases have not been detected in the mortars. 


\section{Chemical characterization}

\subsection{Chemical composition}

- The complete characterization turns out to be the valid reference in order to compare results achieved by others techniques of characterization. The table 1 shows the results from the complete chemical analysis of the major components.

Calcium carbonate (calcium oxide and calcination loss) and silica were the main components determined. Silica content was highest in the Romanesque zone (MC6) (39.13\%), whilst the two zones of the southern lateral nave (first and last sections) (MC3 and MC4) have lower values (19.75\% and 19.11\%). Practically no differences with regard to composition can be seen between these two areas. Only the amount of $\mathrm{CaO}$ (and consequently, of $\mathrm{CaCO}_{3}$ ) seems to be greater in the MC4 than in the MC3 zone.

The sample from the central nave (MC5) was that which in this analysis had lowest values for MgO. In contrast, the sample from the Romanesque foundations had the largest amounts of $\mathrm{Fe}, \mathrm{Al}$ and Ti oxides $\left(\mathrm{R}_{2} \mathrm{O}_{3}=7,23 \%\right)$.

The values of sulphates were low. This indicates that there are not gypsum phases (dihydrated calcium sulphate), which was also confirmed by the X-ray diffraction results. Magnesium amounts were low values, therefore it seems it could discard the presence of dolomite limestone.

- Chemical analysis of the soluble fraction and the insoluble residue

Tables 2 and 3 summarize the results of the chemical analysis of the soluble fraction and the insoluble residue resulting from the attack of the samples using the method proposed.

It was observed that soluble $\mathrm{SiO}_{2}$ had low values. Soluble silica is one the most important parameters in order to establish the hydraulic effect in the samples [8, 9]. The low values in soluble silica could indicate a low hydraulic effect. 
High values in alkaline metals (sodium and potassium) in the samples of zones MC3 and MC4 were observed. This fact may indicate a higher amount of soluble salts.

It has already been pointed out that $\mathrm{Mg}$ presents low percentages. In the soluble fraction analysis, the $\mathrm{MgO}$ values confirm the former results. Percentages of $\mathrm{Fe}_{2} \mathrm{O}_{3}$ and $\mathrm{Al}_{2} \mathrm{O}_{3}$ turn out to be very low. These elements have a important relation with the hydraulic effect. As mentioned previously, this effect coulds present low values.

The objective of the analysis of the insoluble residues is to give a full characterization of the aggregate fraction and to obtain the quantitative chemical composition especially of those components which, due to their low percentages or their non-crystalline nature, could not be detected by X-ray diffraction.

The results obtained are similar in the samples analysed. It can be seen that the major component of the insoluble residue is $\mathrm{SiO}_{2}$ (80-85\%). Fe, $\mathrm{Al}$ and $\mathrm{Ti}$ oxides accounts for 7-9\% and the remainder are minor components which do not exceed $2 \%$.

The aggregate used is fundamentally siliceous and probably associated with it are the non-hydraulic silicates and the clays which are not soluble in acid - those elements responsible for the $\mathrm{Fe}_{2} \mathrm{O}_{3}$ and $\mathrm{Al}_{2} \mathrm{O}_{3}$ contents.

\subsection{Trace elements}

The chemical nature of the trace elements and their relative concentrations indicate the geological history of the material, in function of the parameters that have conditioned them $[10,11]$. Figure 2 shows the graphs of trace metals.

The critical study of these graphs indicates that there are not large differences in the composition of the trace metals analysed among the mortars of the six studied classes. Therefore, it is probable that the materials used proceed from the same quarry. This is logical if one considers the history of the construction of the Cathedral of Pamplona. 
However, the classes MC3 and MC4 have almost identical micro-chemical composition, their raw material proceeds from the same quarry and zone. This also is adjusted to the other results obtained previously in this work.

\subsection{Soluble salts}

In this study a measure of overall conductivity was taken in representative samples from different zones. The aim was to evaluate overall activity in soluble salts that may affect the state of the sample [12]. Results refer to a suspension that contains $1 \mathrm{mg}$ of sample for mL, expressed in $\mu \mathrm{S} . \mathrm{cm}^{-1}$ (Figure 3). The results show low conductivity in general in the mortars analysed, which is indicative of very low levels of total salinity in the samples in comparison with those values found in the bibliography $\left(68-149 \mu \mathrm{S} . c m^{-1}\right)$ [1].

The samples from zones MC3, MC4 and MC5, which belong to the central and southern lateral naves have the highest values of total salinity, and coincide with the previous observations on the degree of homogeneity and the characteristics of the samples, which are in comparatively poor condition and very deteriorated.

The values for conductivity in the aqueous extract and the anion values are shown in the Figure 3.

The results of the determination of anions show quite low $\mathrm{Cl}^{-}$content in comparison to some studies (0.67-2.27\%) [1], although without reaching the extreme values recorded in some studies $(<0.06 \%$, [13]).

Nitrate content is very disparate from sample to sample, ranging from low values, of the order of $0.05 \%$ for zones MC2 and MC5, to values under detection limit for zones MC1 and MC6. The mortars from the MC3 and MC4 show extremely high nitrate values between $1.5-2 \%$. This fact means that the high values in alkaline metals in these zones could be related with these results of nitrate values, and confirms the higher amount of soluble salts expected. This also leads to the hypothesis that the origin of the raw material in the two samples was similar. 
Indeed, these two samples have similar amounts of sulphate ion, which, generally, is present in quite low levels in all the mortars analysed (from 0.007 to $0.089 \%$ ).

In the figure it can be seen that conductivity varies with the amount of chloride ion in the sample, except in those samples from the MC3 and MC4 zones, with large amounts of nitrates which alter this relationship. The greater effect of the chloride ion on the total conductivity of the samples is logical if the following two aspects are borne in mind:

1. Its presence in larger amounts (of the order of a higher scale in percentage terms), except the nitrates in the zones mentioned. This fact has already been highlighted in the bibliography [1], where the chlorides appear as the most frequent soluble salts in the mortars analysed, and even as the only salts to be detected. However, it is not possible to generalise from this, although in mortars from maritime environments a higher content of these anions is to be expected [14].

2. The second aspect to be considered is the high load density of the chloride ion, due to its small ionic radius, which leads it to have a notable effect on conductivity.

One objective of this study was to analyse the association between these variables and to this end a correlation analysis was made of the variables. The matrix is shown in the table 4 .

There is a strong association between the percentage of nitrates and sulphates $(\mathrm{r}=0.827$; $\mathrm{p}=0.022$ ) and an association of moderate strength between conductivity and chlorides $(\mathrm{r}=0.703 ; \mathrm{p}=0.078)$ and nitrates $(\mathrm{r}=0.739 ; \mathrm{p}=0.058)$ (both on the limits of statistical significance), and somewhat less with sulphates ( $\mathrm{r}=0.603 ; \mathrm{p}=0.152)$.

Indeed, the contribution of the cations of these soluble salts to total conductivity has not been taken into consideration; hence the moderate degree of association as these other variables have an effect on total salinity. 
In order to establish a mathematical relationship between conductivity and the percentages of anions, a multiple regression analysis was performed, with conductivity as the dependent variable. The formula that relates total conductivity to the amounts of anions is thus (Eq.1):

$$
\begin{aligned}
& \text { Total conductivity }=-2.43+98.79\left(\% \mathrm{Cl}^{-}\right)+18.72\left(\% \mathrm{NO}_{3}{ }^{-}\right) \\
& \qquad\left(\mathrm{R}^{2}=0.987 ; \mathrm{p}=0.0002 * * *\right)
\end{aligned}
$$

The squared multiple regression coefficient $\mathrm{R}^{2}$ gives the proportion of the total variance of the dependent variable (total conductivity) which is explained by the independent variables (percentages of anions) with a highly significant probability associated with the model proposed. In the samples analysed, sulphates so not significantly influence conductivity, probably as a result of their low percentages. This model corroborates the fact that chloride ion exerts a greater effect than the other two anions on the total salinity of the mortars from cathedral of Pamplona.

\section{Mineralogical study}

\subsection{Mineralogical aggregate composition}

In this study X-ray diffraction of the insoluble residue from the proposed chemical attack was performed. The results obtained were compared with data from the ICDD powder diffraction file. The results, as shown in table 5, show that the composition of the insoluble residue, attributable to the aggregate fraction of the sample, is principally $\alpha-\mathrm{SiO}_{2}$. Non-hydraulic silicates that exhibit diffraction peaks were studied and no differences were found in types or quantities of mica derivatives (ICDD pattern 78-1928) and others silicates. Slight variations were detected in clays of the smectite group and also in kaolinites $\left(\mathrm{Al}_{2}(\mathrm{OH})_{4} \mathrm{Si}_{2} \mathrm{O}_{5}\right)$ (ICDD pattern 83-971). Tobermorite (hydraulic silicate $\mathrm{Ca}_{2,25}\left(\mathrm{Si}_{3} \mathrm{O}_{7,5} \mathrm{OH}_{1,5}\right) \cdot\left(\mathrm{H}_{2} \mathrm{O}\right)$ (ICDD pattern 83-1520) was not found within the insoluble residue of the attacks. In general, the complex silicates diffraction peaks occur very closely together as a result of which individual identification of these components is difficult. 
No diffraction peaks for calcite are seen as it has already supposedly been solubilized after the acid attack. The diffraction patterns for the samples are very similar and no differences can be established between those from different zones. However, this analysis serves to establish an initial qualitative and semi quantitative composition of the aggregate fraction, provided that, as is the case with the samples analysed, this is siliceous in nature.

\subsection{Aggregate granulometric fractions}

The distribution characteristics of the grain size of the arid through a granulometric study have also been undertaken. Figure 4 shows the granulometric distribution for MC1 zone. The differences between the others zones are stated below.

The grading of the aggregate (after dissolution of the binding material with $\mathrm{HCl} 1: 1$ ) shows that for the clay fraction $(<0.1 \mathrm{~mm})$ all the samples give very high values, in excess of $20 \%$; with the exception of the sample from the Romanesque foundations (MC6 zone). Samples from MC3 and MC4 zones offer very similar percentages.

The fine sand fraction $(0.25-0.50 \mathrm{~mm})$ is in percentage terms the most important fraction of all the aggregates analysed, especially the material retained by the $0.25 \mathrm{~mm}$ and $0.50 \mathrm{~mm}$ sieves (66\% in zone MC1; 55\% in MC2; about 50\% for MC3 and MC4; 53\% in MC5 zone, and, with the highest values, $80 \%$ for MC6). The amount of material retained by the $0.05 \mathrm{~mm}$ sieve in MC3 and MC4 was particularly low.

In the intermediate sand (1-1.6 mm), MC1 contains the lowest percentage of retained material (Figure 4). MC2 offers high values in this fraction, together with MC5. Intermediate values (4-6\%) are present in MC3 and MC4 (with very similar distributions) and MC6 zone. In the coarse sand fraction (2-4 mm) there is great variability with MC6 and MC1 (1 and 2\% respectively) offering the lowest percentages. 
In order to catalogue the grading distribution curves of the aggregates two geological parameters were used: the median and the "sorting index" (the quotient between the $3^{\text {rd }}$ and $1^{\text {st }}$ quartile expressed in $\mathrm{mm}$ ) [15]. The results are shown in the Table 6.

The median is used to gauge the fineness of a sand. Median values ranging from $0.5 \mathrm{~mm}$ to $1.6 \mathrm{~mm}$ correspond to intermediate sands. In this study, all the mortars analysed have mainly fine sands in their composition. The sorting index gives an idea of the good or bad choice of a sand for a mortar (an appropriate staging in the percentages of the different fractions): a $\mathrm{S}_{\mathrm{O}}<$ 2.5 would indicate a well chosen sand, whereas a $\mathrm{S}_{\mathrm{O}}>4.5$ would indicate the contrary. In this study MC2 and MC5 zones would have a badly distributed sand, and only MC6 zone could be considered as adequate. However, both median and $\mathrm{S}_{\mathrm{O}}$ must be interpreted with caution. It is not possible to extrapolate from them and there must be a full awareness of the limitations of the information they provide. Any claims cannot be definitive as they only partially evaluate all the characteristics of the distribution of the aggregate

Furthermore, it can be confirmed that the aggregate used in zones MC3 and MC4 is, with probability, the same.

\section{Thermal studies}

Interpretation of the thermo-analytical curves obtained offers the results conteined in Table 7. Differential thermal and thermogravimetric analysis are suitable in order to establish characteristics of the ancient mortars: it is easy the detection of main components, the nature of the aggregate and other aspects, while the small quantity of sample. These temperature range correspond approximately to the percentage of humidity $\left(20^{\circ}-120^{\circ} \mathrm{C}\right)$, loss of chemically bound water (indicative of hydraulic compounds) $\left(300^{\circ}-550^{\circ} \mathrm{C}\right)$, decarbonation of magnesium carbonate $\left(550^{\circ}-610^{\circ} \mathrm{C}\right)$ and decarbonation of calcite $\left(610^{\circ}-880^{\circ} \mathrm{C}\right)$.

In the DTA curve obtained for the zone $\mathrm{MC} 1$, an endothermic peak at $570^{\circ} \mathrm{C}$ has been observed (Figure 5). This peak colud be related with the transformation (Eq. 2) 


$$
\alpha-\mathrm{SiO}_{2} \rightarrow \beta-\mathrm{SiO}_{2} \mathrm{~T}^{\mathrm{a}}=573^{\circ} \mathrm{C}[16,17]
$$

because there is not an associated weight loss.

The measured curve is followed by a step between $610^{\circ}$ and $800^{\circ} \mathrm{C}$ (with a minimum at $705^{\circ} \mathrm{C}$ ) due to the decomposition of calcium carbonate which can be estimated in the order of $22 \%$ of the total original weight (Eq. 3).

$$
\mathrm{CaCO}_{3} \rightarrow \mathrm{CaO}+\mathrm{CO}_{2}
$$

A similar step for the sample MC2, related to the calcite decarbonation, with a minimum at $724^{\circ} \mathrm{C}$ is also evaluated. A not clearly marked peak, due to the change of $\alpha-\mathrm{SiO}_{2}$ in $\beta-\mathrm{SiO}_{2}$ is observed. For the measured curves of MC3, MC4 and MC5 zones, the steps similar to MC1 zone (Figure 5) for the calcite decomposition were obtained. In most of cases carbonates decompose bellow $600^{\circ} \mathrm{C}$, in accordance with the data of the literature [18-20].This fact also occurs for the MC6 curve, but the minimum (at $706^{\circ} \mathrm{C}$ ) is obtained at a minor temperature (Figure 6). The decrease in decomposition temperature has been related to the presence of soluble salts, for example, that favour decomposition, and also to the dimension and defective state crystal lattice, even to the process of carbonation [18, 21, 22]. The transformation of $\alpha-\mathrm{SiO}_{2}$ in $\beta-\mathrm{SiO}_{2}$ is also showed in this MC6 curve.

An important weight loss in the TG curve at $370^{\circ} \mathrm{C}$, and other at $450^{\circ} \mathrm{C}$ were detected in MC6 curve. These losses could have an explanation in the fact of the loss of volatile substances present in the mortar, for the $1^{\text {st }}$ loss. The $2^{\text {nd }}$ loss could be related to the combustion of the carbon who had been formed in the previous carbonization.

Obviously, the loss of this organic matter could give an weight loss explanation to the results that shows the highest percentage between $300^{\circ}$ and $550^{\circ} \mathrm{C}$ for all the samples (5.49\%). But the weight losses in this range may be attributed to the chemically bound water, and can be indicative of the presence of hydraulic compounds. These hydraulic compounds, probably calcium silico-aluminate hydrates, can have a different origin: a lime/ceramic reaction, the 
employment of limes of marly nature, or the aggregate added after lime calcination, with an intentional or uninentional addition.

The loss value shows an agreement with the results of a previous study that refers this weight loss to the hydraulic water $[17,18]$. Besides, these hydraulic silicates (CSH) might confirm the previous results of chemical analysis for MC6, with the highest percentage of Fe, $\mathrm{Al}$ and Ti oxides.

Significant amounts of $\mathrm{MgCO}_{3}$ have not been detected in any samples, because low weight losses have been found between $550^{\circ}$ and $610^{\circ} \mathrm{C}$. Furthermore, the three endothermic peaks at $250^{\circ}, 384^{\circ}$ and $441^{\circ} \mathrm{C}$, caused by the decomposition of the hydromagnesite have not been detected, together with a loss weight between $220^{\circ}$ and $460^{\circ} \mathrm{C}$ in the TG curve. When the shrinkage occurs, the $\mathrm{MgCO}_{3}$ hydrolysis should generate hydromagnesite $\left(\mathrm{Mg}_{5}\left(\mathrm{CO}_{3}\right)_{4}(\mathrm{OH})_{2} \cdot 4 \mathrm{H}_{2} \mathrm{O}\right)$. The three endothermic peaks are related to the hydration water loss, the residual hydration water loss and the $\mathrm{OH}^{-}$loss [23-25].

In the case of presence of hydromagnesite an exothermic peak at $550^{\circ} \mathrm{C}$, due to the crystallization of $\mathrm{xMgCO}_{3}$ y $\mathrm{MgO}$ phase should be observed. However, it has been observed that the presence of impurities, such as $\mathrm{Ca}^{2+}$ or $\mathrm{Cl}^{-}$decreases the intensity of this peak. In the analyzed mortars the absence of this crystallization peak is most probable due to the presence of $\mathrm{Ca}^{2+}$.

In any case, calcite decomposition in the DTA curves seems to occur in a continuous form, without steps. This fact can be due to the absence of different degrees of crystallinity in the $\mathrm{CaCO}_{3}$. Calcitic aggregate should show different steps of decomposition, because the recarbonated calcite [26], formed after calcination, losses the $\mathrm{CO}_{2}$ at a lower temperature than natural calcites. This effect is due to the large size of the crystals in the calcareous aggregates compared to the microcrystalline structure of the recarbonated calcite. In accordance to the XRD results, peaks of gypsum phases have not been found in any sample. 
It has already been pointed out that the resemblance between the samples MC3 and MC4. This similarity was confirmed by the closeness of the zones in the building. The difference in $\mathrm{CO}_{2}$ percentage in the TG curves between the two samples was $2.52 \%$. This means a difference of $5.72 \%$ in $\mathrm{CaCO}_{3}$. This difference of $\mathrm{CaCO}_{3}$ involves a value of $\mathrm{CaO}$ percentage $3.20 \%$ higher in the MC4 zone than in the MC3 zone. However, only a difference of $1.51 \%$ in $\mathrm{CaO}$ has been determined in the previous chemical analysis. The similarity among both samples given (macro and microchemical results) it can rule out that te $1.69 \%$ of $\mathrm{CaO}$ comes from other compounds. Therefore, it must be pointed out that this $\mathrm{Ca}$ was present as $\mathrm{CaO}$, better hydrated, $\mathrm{Ca}(\mathrm{OH})_{2}$. This means that the $4.5 \%$ of the initial $\mathrm{Ca}(\mathrm{OH})_{2}$ in the $\mathrm{MC} 3$ zone have not been carbonated.

\section{Conclusions}

All mortars studied in the Pamplona cathedral are mortars with lime binder (they can be classified by the type of ordinary limes) and a silica aggregate.

1. Only the MC6 sample has shown a certain hydraulic effect, with a good agreement between the results from macrochemical and microchemical analysis and DTA-TGA studies. However, in the other mortars, the hydraulic effect can be considered to be non-existent.

2. The calculation of the initial weight percentages of raw materials has given the values collected in Table 8 for each class of mortar. The formulas used to calculate these percentages are showed as follows (Eq. 4-6). They are based in a previous study with slight modifications [27].

$$
\% \mathrm{Ca}(\mathrm{OH})_{2}=\frac{\frac{\mathrm{A}}{1,351}}{100-\left[\mathrm{A}-\frac{\mathrm{A}}{1,351}\right]} 100=\frac{\frac{\mathrm{A}}{1,351}}{100-[0,260 \mathrm{~A}]} 100
$$


where $\mathrm{A}$ is $\% \mathrm{CaCO}_{3}$ calculated in TG studies (temperature ranges between $610^{\circ}$ and $880^{\circ} \mathrm{C}$, associated with $\mathrm{CO}_{2}$ loss) (Table 7).

$$
\text { \%Aggregate }=\frac{\% \mathrm{IR}}{100-\left[\mathrm{A}-\frac{\mathrm{A}}{1,351}\right]} 100=\frac{\% \mathrm{IR}}{100-[0,260 \mathrm{~A}]} 100
$$

where IR is the insoluble residue calculated in the chemical analysis [7]

$$
\% \text { Water }=100-\left[\% \mathrm{Ca}(\mathrm{OH})_{2}+\% \text { Aggregate }\right]
$$

Assuming that the increase in weight of the original sample to the present sample is due exclusively to the decarbonation of the slaked lime, a quite approximate theoretical calculation can be made as to the initial percentages of the raw materials used in the elaboration of the mixtures. Table 8 shows what can be supposed to be the initial composition by percentage weight of the type of mortar from each zone.

4. The determined in weight binder/aggregate relationship in the classes of mortars responds to a normal quotient (between 0.5-2.5 approximately, according to the results from the literature [28-30]).

5. Thermal analysis have permitted to establish that the difference between MC3 and MC4 mortars is due to an incomplete carbonation in MC3. Also, the existence of dolomite, gypsum phases and calcareous aggregate has not been proven by thermal methods.

6. The samples under study do not show high values for soluble salts. Chlorides and nitrates are the anions which affect the total conductivity of the aqueous extract, according to the correlation established.

7. The DTA-TGA studies have shown a good agreement with the other characterization techniques, and they have been checked as a good method for the analysis of the ancient mortars. 
8. From the analysis carried out by chemical, mineralogical and petrographic methods, it can be concluded that the choice of the raw materials was made from local sources. MC3 and MC4 classes, with the highest values in soluble salts (alkaline nitrates) could present an important risk of deterioration. 


\section{References}

1. G. Alessandrini, R. Bugini, R. Negrotti, L. Toniolo. Eur. J. Mineral. 3 (1991) 619-627.

2. A.E. Charola, M. Dupas, R.P. Sheryll, G.G. Freund. In: P.L. Parrini, Ed. Proc. Int. Symposium Scientific Methodologies Applied to Works of Art. Montedison Progetto Cultura, Arcadia, Milan, 1986, pp. 28-33.

3. M. Frizot. In: Proc. Symposium Int. Centre for the study of the preservation and the restoration of cultural property, Rome, 1981, pp. 331-339.

4. A. Macías, J. De Frutos, M.T. Blanco, F. Puertas. In: J. Delgado, F. Henriques, F. Telmo, Eds. Proc. 7th Int. Congress on Deterioration and Conservation Stone. Lab. Nac. de Engenharia, Lisbon, 1992, pp. 1213-1221.

5. J.I. Alvarez, A. Martín, P.J. García Casado. In: J. Riederer, Ed. Proc. 8th Congress Int. on Deterioration and Conservation of Stone, Berlin, 1996, pp. 1457-1470.

6. J.I. Alvarez, A. Martín, P.J. García Casado, I. Navarro, A. Zornoza. Cement and Concrete Research 29 (1999) 1061-1065.

7. J.I. Alvarez, A. Martín, P.J. García Casado. In: E. M. Sebastián, I. Valverde, U. Zezza, Eds. Proc. III Congreso Int. de Rehabilitación del Patrimonio Arquitectónico y Edificación, Granada, 1996, pp. 256-260.

8. J.E. Lindqvist, B. Schouenborg, M. Sandström, H. Sandström, K. Sandin, E. Sidmar. Proc. Int. Conf. Cem. Microsc. 1994, pp. 306-322.

9. F.X. Deloye. Bull. liaison Labo. P.et Ch. 175 (1991) 59-65.

10. M.A. Bello, A. Martín. Archaeometry. 34 (1992) 21-29.

11. M.J. De la Torre, J. Rodríguez, E.M. Sebastián. In: IV Congreso de geoquímica de España, Soria, 1991, pp. 470-478. 
12. M.J. De la Torre, J. Rodríguez, E.M. Sebastián. In: J. Delgado, F. Henriques, F. Telmo, Eds. Proc. 7th Congress International on Deterioration and Conservation of Stone. Lab. Nac. de Engenharia, Lisbon, 1992, pp. 1177-1185.

13. M.T. Blanco-Varela, F. Puertas, A. Macías, A. Palomo. In: J. Delgado, F. Henriques, F. Telmo, Eds. Proc. 7th Congress International on Deterioration and Conservation of Stone. Lab. Nac. de Engenharia, Lisbon, 1992, pp. 1299-1305.

14. R. Malinowski, A. Slatkine, M. Ben Yair. Durability of Roman mortars and concretes for hydraulic structures at Caesarea and Tiberias. RILEM, Prague, 1961.

15. M. Frizot. Mortiers et enduits peints antiques- étude technique et archéologique. Ed. Centre de Recherches sur les techniques gréco-romains. Université de Dijon. 1975.

16. N.N. Greenwood, A.Earnshaw. Chemistry of the elements. Pergamon Press, Oxford, 1984, p.394.

17. A. Moropoulou, A. Bakolas, K. Bisbikou. Thermochim Acta, 269 (1995) 779-795.

18. A. Bakolas, G. Biscontin, A. Moropoulou, E. Zendri. Thermochim Acta, 321 (1998) 151-160.

19. J. Adams, D. Dollimore, D.L. Griffiths. J. Thermal Anal. 40 (1993) 275-284.

20. L. Paama, I. Pitkänen, H Rönkkömäki, P. Perämäki. Thermochim Acta, 320 (1998) 127-133.

21. G. Martinet, F Deloye, J.C. Golvin. Bull. liaison Labo. P. et Ch. 181 (1992) 39-45.

22. G. Martinet, F. Deloye, A. Le Roux. Bull. liaison Labo. P. et Ch. 182 (1992) 21-26.

23. C. Fiori, M. Macchiarola. In: E. M. Sebastián, I. Valverde, U. Zezza, Eds. Proc. III Congreso Int. de Rehabilitación del Patrimonio Arquitectónico y Edificación, Granada, 1996, pp. 223-237.

24. S. Veccio, A. Laginestra, A. Frezza, C. Ferragina. Thermochimica Acta, 227 (1993) 215-223. 
25. S. Bruni, F. Cariati, P. Fermo, A. Pozzi, L. Toniolo. Thermochimica Acta, 321 (1998) 161-165.

26. A. Reller, P.M. Wilde, H.G. Wiedemann, H. Hauptmann, G. Bonani. Mat. Res. Soc. Symp. Proc. 267 (1992) 107-1011.

27. G. Alessandrini, R. Bugini, L. Folli, M. Realini, L. Toniolo. In: J. Delgado, F. Henriques, F. Telmo, Eds. Proc. 7th Congress International on Deterioration and Conservation of Stone. Lab. Nac. de Engenharia, Lisbon, 1992, pp. 667-675.

28. P. Hoffman, G. Vetter. Fresen. J. Anal. Chem. 338 (1990) 133-137.

29. G. Alessandrini, G Dassù, R. Bugini, L. Formica. Studies in Conservation. 29 (1984) 161-171.

30. F Gutiérrez-Solana, M. Jauregui, R. Bohigas, P. Sarabia. Materiales de Construcción. 39 (1989) 37-45. 
Table 1. Complete chemical analysis of the samples.

\begin{tabular}{lcccccccccc}
\hline Zone & $\mathbf{L o s s}^{\mathbf{a}}$ & $\begin{array}{c}\mathrm{SiO}_{\mathbf{2}}^{\mathbf{b}} \\
\mathbf{( \% )}\end{array}$ & $\begin{array}{c}\mathbf{C a O} \\
\mathbf{( \% )}\end{array}$ & $\begin{array}{c}\mathbf{M g O} \\
\mathbf{( \% )}\end{array}$ & $\begin{array}{c}\mathbf{F e}_{\mathbf{2}} \mathbf{O}_{\mathbf{3}} \\
\mathbf{( \% )}\end{array}$ & $\begin{array}{c}\mathrm{Al}_{\mathbf{2}} \mathbf{O}_{\mathbf{3}} \\
\mathbf{( \% )}\end{array}$ & $\begin{array}{c}\mathbf{T i O}_{\mathbf{2}} \\
\mathbf{( \% )}\end{array}$ & $\begin{array}{c}\mathrm{SO}_{\mathbf{3}} \\
\mathbf{( \% )}\end{array}$ & $\begin{array}{c}\mathbf{N a}_{\mathbf{2}} \mathbf{O} \\
\mathbf{( \% )}\end{array}$ & $\begin{array}{c}\mathbf{K}_{\mathbf{2}} \mathbf{O} \\
\mathbf{( \% )}\end{array}$ \\
\hline MC1 & 27.48 & 29.37 & 32.98 & 2.49 & 5.18 & 0.30 & 0.15 & 0.81 & 0.28 & 0.55 \\
MC2 & 32.27 & 22.18 & 37.56 & 2.49 & 3.32 & 0.99 & 0.48 & 0.63 & 0.26 & 0.47 \\
MC3 & 34.50 & 19.75 & 36.90 & 3.48 & 2.81 & 0.69 & 0.48 & 0.69 & 0.28 & 0.45 \\
MC4 & 34.01 & 19.11 & 38.42 & 4.08 & 2.30 & 0.86 & 0.39 & 0.65 & 0.17 & 0.42 \\
MC5 & 30.43 & 23.66 & 37.42 & 0.98 & 5.50 & 0.27 & 0.18 & 0.78 & 0.19 & 0.59 \\
MC6 & 23.35 & 39.13 & 26.34 & 2.12 & 6.60 & 0.49 & 0.14 & 0.82 & 0.22 & 0.66 \\
\hline
\end{tabular}

Sodium carbonate - borax alkaline flux.

Percentages related to original dry mortar.

${ }^{\text {a }}$ Calcination loss at $975-1000^{\circ} \mathrm{C}$.

${ }^{\mathrm{b}}$ Total silica in the sample.

Table 2. Chemical analysis of the soluble fraction after hot hydrocloric acid attack.

\begin{tabular}{cccccccc}
\hline Sample & $\begin{array}{c}\mathrm{SiO}_{\mathbf{2}}{ }^{\mathbf{a}} \\
\mathbf{( \% )}\end{array}$ & $\begin{array}{c}\mathrm{CaO} \\
\mathbf{( \% )}\end{array}$ & $\begin{array}{c}\mathbf{M g O} \\
\mathbf{( \% )}\end{array}$ & $\begin{array}{c}\mathbf{F e}_{\mathbf{2}} \mathbf{O}_{\mathbf{3}} \\
\mathbf{( \% )}\end{array}$ & $\begin{array}{c}\mathrm{Al}_{\mathbf{2}} \mathbf{O}_{\mathbf{3}} \\
\mathbf{( \% )}\end{array}$ & $\begin{array}{c}\mathbf{N a}_{\mathbf{2}} \mathbf{O} \\
\mathbf{( \% )}\end{array}$ & $\begin{array}{c}\mathbf{K}_{\mathbf{2}} \mathbf{O} \\
\mathbf{( \% )}\end{array}$ \\
\hline MC1 & 0.50 & 32.67 & 2.71 & 4.34 & 0.66 & 0.035 & 0.098 \\
MC2 & 0.57 & 37.20 & 2.23 & 3.23 & 0.56 & 0.037 & 0.062 \\
MC3 & 0.55 & 36.90 & 2.40 & 2.98 & 0.60 & 0.151 & 0.138 \\
MC4 & 0.62 & 38.41 & 2.28 & 2.86 & 0.70 & 0.114 & 0.191 \\
MC5 & 0.89 & 36.65 & 0.96 & 3.46 & 0.79 & 0.048 & 0.125 \\
MC6 & 0.37 & 31.23 & 1.70 & 6.92 & 0.69 & 0.031 & 0.095 \\
\hline
\end{tabular}

Percentages related to original dry mortar

${ }^{\mathrm{a}}$ Acid soluble silica

Table 3. Chemical analysis of the insoluble residue obtained after hot hydrocloric acid attack.

\begin{tabular}{ccccccccccc}
\hline Sampl & $\begin{array}{c}\mathbf{L o s s}^{\mathbf{a}} \\
\mathbf{( \% )}\end{array}$ & $\begin{array}{c}\mathrm{SiO}_{2}^{\mathbf{b}} \\
\mathbf{( \% )}\end{array}$ & $\begin{array}{c}\mathbf{C a O} \\
\mathbf{( \% )}\end{array}$ & $\begin{array}{c}\mathbf{M g O} \\
\mathbf{( \% )}\end{array}$ & $\begin{array}{c}\mathbf{F e}_{\mathbf{2}} \mathbf{O}_{3} \\
\mathbf{( \% )}\end{array}$ & $\begin{array}{c}\mathrm{Al}_{\mathbf{2}} \mathbf{O}_{3} \\
\mathbf{( \% )}\end{array}$ & $\begin{array}{c}\mathbf{T i O}_{\mathbf{2}} \\
\mathbf{( \% )}\end{array}$ & $\begin{array}{c}\mathrm{SO}_{3} \\
\mathbf{( \% )}\end{array}$ & $\begin{array}{c}\mathbf{N a}_{\mathbf{2}} \mathbf{O} \\
\mathbf{( \% )}\end{array}$ & $\begin{array}{c}\mathbf{K}_{\mathbf{2}} \mathbf{O} \\
\mathbf{( \% )}\end{array}$ \\
\hline $\mathbf{M C 1}$ & 1.91 & 85.78 & - & 1.19 & 7.22 & 1.31 & 0.26 & 0.57 & 1.09 & 1.29 \\
$\mathbf{M C 2}$ & 3.31 & 84.31 & - & 2.02 & 6.32 & 2.15 & 0.64 & 0.61 & 0.60 & 0.27 \\
$\mathbf{M C 3}$ & 2.80 & 85.19 & - & 1.84 & 5.68 & 1.73 & 0.64 & 0.66 & 0.72 & 0.61 \\
$\mathbf{M C 4}$ & 2.73 & 85.66 & - & 1.58 & 5.28 & 1.96 & 0.89 & 0.64 & 0.70 & 0.56 \\
$\mathbf{M C 5}$ & 4.21 & 83.27 & - & 1.37 & 6.85 & 1.77 & 0.23 & 0.56 & 0.89 & 0.85 \\
$\mathbf{M C 6}$ & 2.00 & 88.16 & - & 1.26 & 6.17 & 0.70 & 0.14 & 0.72 & 0.47 & 0.73 \\
\hline
\end{tabular}

Sodium carbonate - borax alkaline flux.

Percentages related to the sample of dry insoluble residue.

${ }^{\text {a }}$ Calcination loss at $975-1000^{\circ} \mathrm{C}$.

$\mathrm{b}$ Total silica in the sample. 
Table 4. Matrix to correlation of the anions.

\begin{tabular}{|c|c|c|c|c|}
\hline Parameters & $\begin{array}{l}\mathrm{Cl}^{-} \\
(\%)\end{array}$ & $\begin{array}{l}\mathrm{NO}_{3}^{-} \\
(\%)\end{array}$ & $\begin{array}{c}\% \mathrm{SO}_{4}^{2-} \\
(\%)\end{array}$ & $\begin{array}{c}\text { Conductivity } \\
\left(\mu{\left.\mathrm{S} . \mathrm{cm}^{-1}\right)}^{-1}\right.\end{array}$ \\
\hline $\mathrm{Cl}^{-}(\%)$ & 1 & & & \\
\hline$\% \mathrm{NO}_{3}^{-}(\%)$ & 0.055 & 1 & & \\
\hline$\% \mathrm{SO}_{4}^{2}-(\%)$ & -0.036 & 0.827 & 1 & \\
\hline Cond. $\left(\mu S . \mathrm{cm}^{-1}\right)$ & 0.703 & 0.739 & 0.603 & 1 \\
\hline
\end{tabular}

Table 5. X-ray diffraction of the insoluble fraction.

\begin{tabular}{|c|c|c|c|c|c|}
\hline Zone & $\begin{array}{c}\text { Silica } \\
\mathrm{SiO}_{2} \\
\text { ICDD 85-798 }\end{array}$ & $\begin{array}{c}\text { Muscovite } \\
\left(\mathrm{K}_{0,93}, \mathrm{Na}_{0,03}\right)\left(\mathrm{Al}_{1.54}\right. \\
\left.\mathrm{Fe}_{0,25}, \mathrm{Mg}_{0,21}, \mathrm{Ti}_{0,04}\right) \\
\left(\left(\mathrm{Si}_{3,34}, \mathrm{Al}_{0,66}\right) \mathrm{O}_{10}\right) \\
(\mathrm{OH})_{2} \\
\text { ICDD 82-1852 }\end{array}$ & $\begin{array}{c}\text { Anorthite } \\
\mathrm{Ca}\left(\mathrm{Al}_{2} \mathrm{Si}_{2} \mathrm{O}_{8}\right) \\
\text { ICDD 76-948 }\end{array}$ & $\begin{array}{c}\text { Albite } \\
\mathrm{Na}\left(\mathrm{AlSi}_{3} \mathrm{O}_{8}\right) \\
\mathrm{ICDD} 76-898\end{array}$ & $\begin{array}{c}\text { Feldspar } \\
\mathrm{Na}_{0,5} \mathrm{~K}_{0,5} \mathrm{AlSi}_{3} \mathrm{O}_{8} \\
\text { ICDD 84-710 }\end{array}$ \\
\hline MC1 & $* * *$ & $\mathrm{~s}$ & - & $\mathrm{t}$ & $\mathrm{t}$ \\
\hline MC2 & $* * *$ & $\mathrm{t}$ & - & - & - \\
\hline MC3 & $* * *$ & $\mathrm{~S}$ & - & $\mathrm{S}$ & - \\
\hline MC4 & $* * *$ & S & - & $\mathrm{s}$ & - \\
\hline MC5 & $* * *$ & $\mathrm{~s}$ & $\mathrm{p}$ & $\mathrm{s}$ & - \\
\hline MC6 & $* * *$ & $\mathrm{~S}$ & - & $\mathrm{t}$ & - \\
\hline
\end{tabular}

Table 6. Median and sorting-index.

\begin{tabular}{ccc}
\hline Zone & Median & So (sorting-index) \\
\hline MC1 & 0.220 & 3.05 \\
MC2 & 0.237 & 5.34 \\
MC3 & 0.205 & 3.69 \\
MC4 & 0.206 & 3.38 \\
MC5 & 0.225 & 5.07 \\
MC6 & 0.230 & 1.51 \\
\hline
\end{tabular}


Table 7. Thermogravimetric analysis: temperature ranges and associated losses.

\begin{tabular}{ccccc}
\hline \multirow{2}{*}{ ZONE } & \multicolumn{4}{c}{ Temperature ranges $\left({ }^{\circ} \mathbf{C}\right)$ and associated losses (\%) } \\
\cline { 2 - 5 } & $\mathbf{2 0}^{\mathbf{0}} \mathbf{- 1 2 0 ^ { \circ }}$ & $\mathbf{3 0 0}^{\mathbf{}} \mathbf{- 5 5 0 ^ { \circ }}$ & $\mathbf{5 5 0}^{\mathbf{0}} \mathbf{- 6 1 0}$ & $\mathbf{6 1 0}^{\mathbf{0}} \mathbf{- 8 8 0}$ \\
\hline & & & & \\
MC1 & 0.503 & 1.858 & 0.830 & 22.274 \\
MC2 & 0.253 & 2.107 & 0.821 & 28.291 \\
MC3 & 0.965 & 2.676 & 0.811 & 28.120 \\
MC4 & 0.849 & 2.717 & 0.871 & 30.637 \\
MC5 & 0.298 & 1.831 & 0.681 & 28.614 \\
MC6 & 1.212 & 5.486 & 0.702 & 18.456 \\
\hline
\end{tabular}

Table 8. Approximate original composition of the classes of mortars (weight percentages).

\begin{tabular}{ccccc}
\hline Zone & $\begin{array}{c}\mathbf{C a}(\mathbf{O H})_{\mathbf{2}} \\
\mathbf{( \% )}\end{array}$ & $\begin{array}{c}\text { Aggregate } \\
\mathbf{( \% )}\end{array}$ & $\begin{array}{c}\text { Water of } \\
\text { constitution(\%) }\end{array}$ & $\begin{array}{c}\text { Relation } \\
\text { binder-aggre } \\
\text { gate }\end{array}$ \\
\hline MC1 & 43.14 & 40.66 & 16.20 & 1.06 \\
MC2 & 57.14 & 31.53 & 11.33 & 1.81 \\
MC3 & 59.40 & 26.25 & 14.35 & 2.26 \\
MC4 & 62.91 & 24.29 & 12.80 & 2.58 \\
MC5 & 57.92 & 33.66 & 8.42 & 1.72 \\
MC6 & 34.84 & 51.57 & 13.59 & 0.68 \\
\hline
\end{tabular}
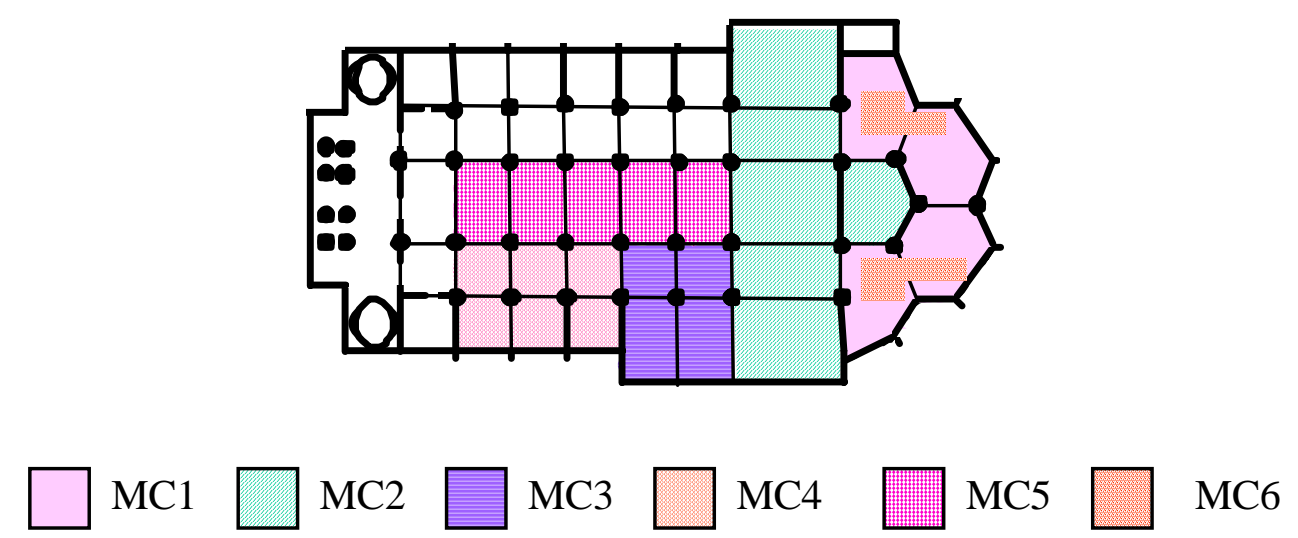

Figure 1. Plan of Pamplona Cathedral. Sampling areas. 


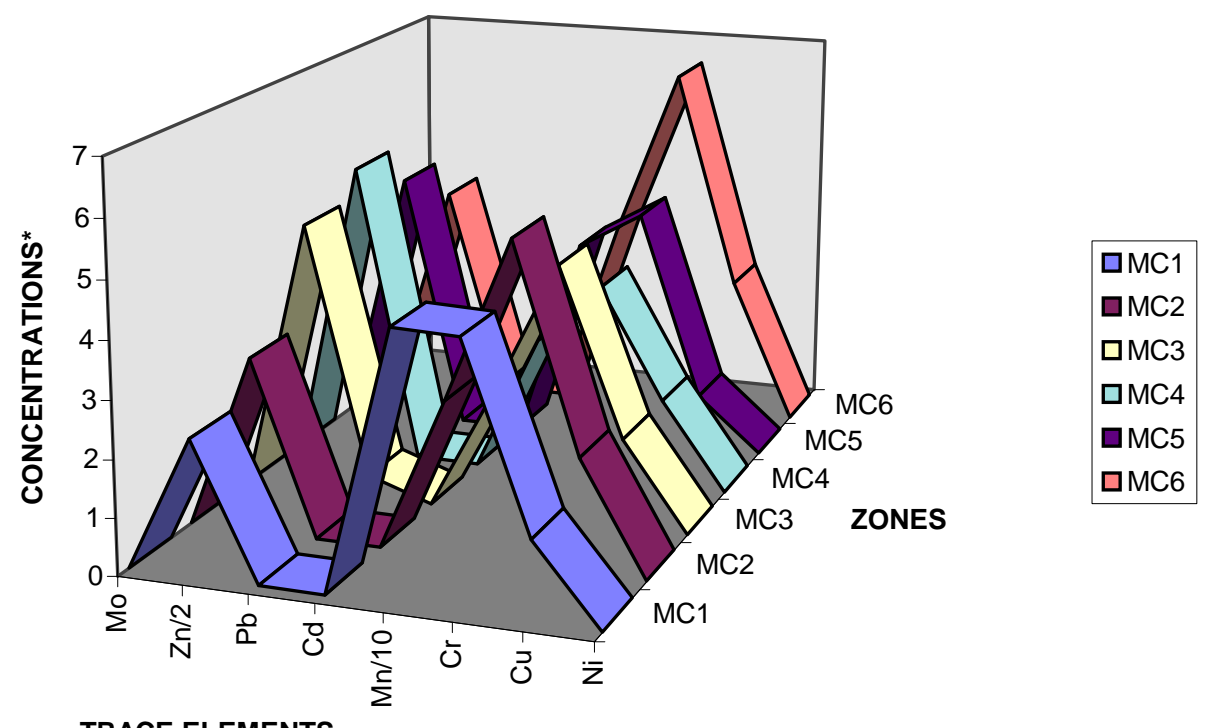

Figure 2. Concentrations of trace elements $\left({ }^{*}\right.$ Concentrations are expressed in $\mu \mathrm{g} / \mathrm{g}$ of sample, Zn and Mn concentrations are divided by 2 and 10, respectively, in order to balance the scales).

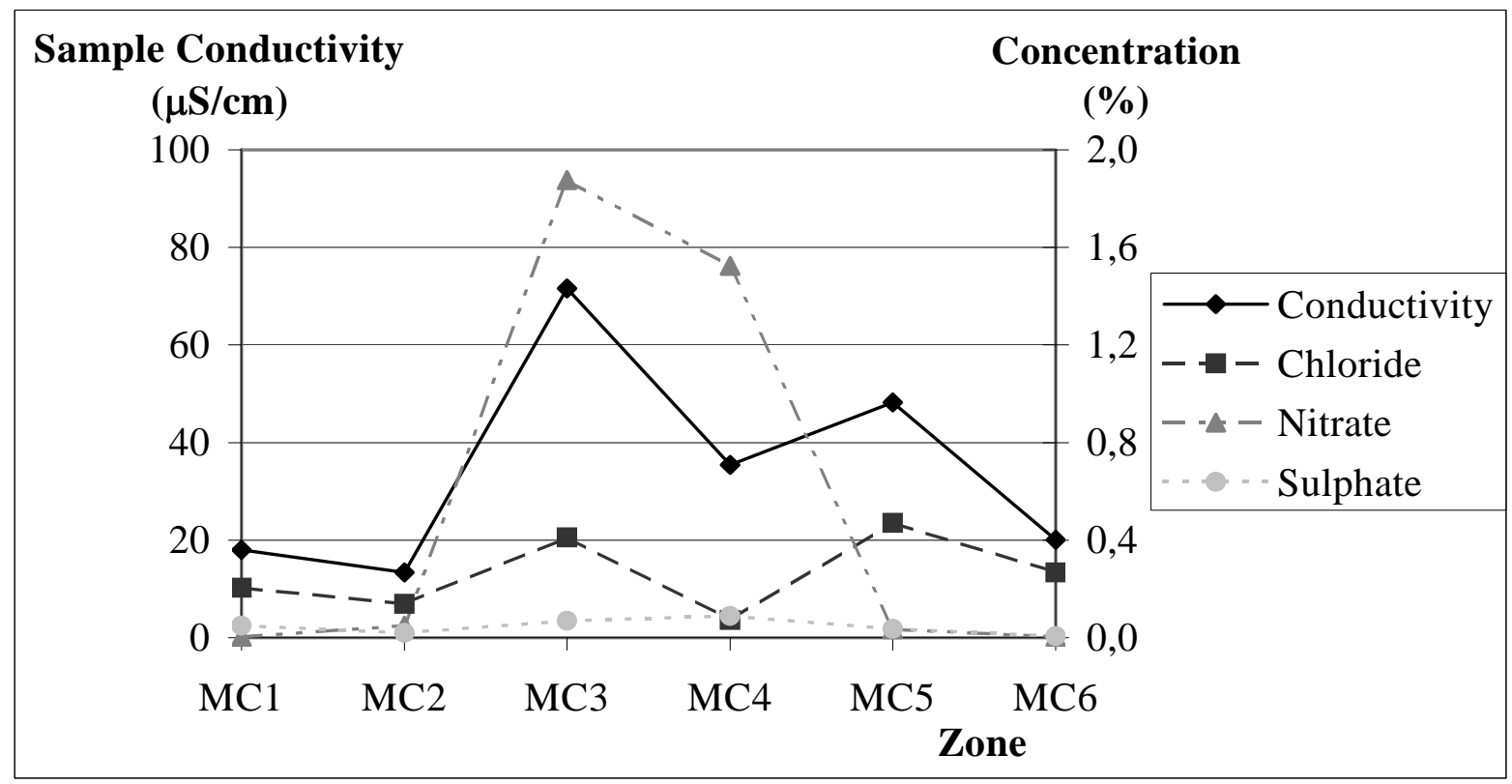

Figure 3. Results of sample conductivity and anions concentration determined by ion chromatography (Conductivity, expressed in $\mu \mathrm{S} . \mathrm{cm}^{-1}$ is given for a suspension of $1 \mathrm{mg}$ of the sample per $\mathrm{mL}$. The concentrations of anions are expressed as percentages of the samples). 


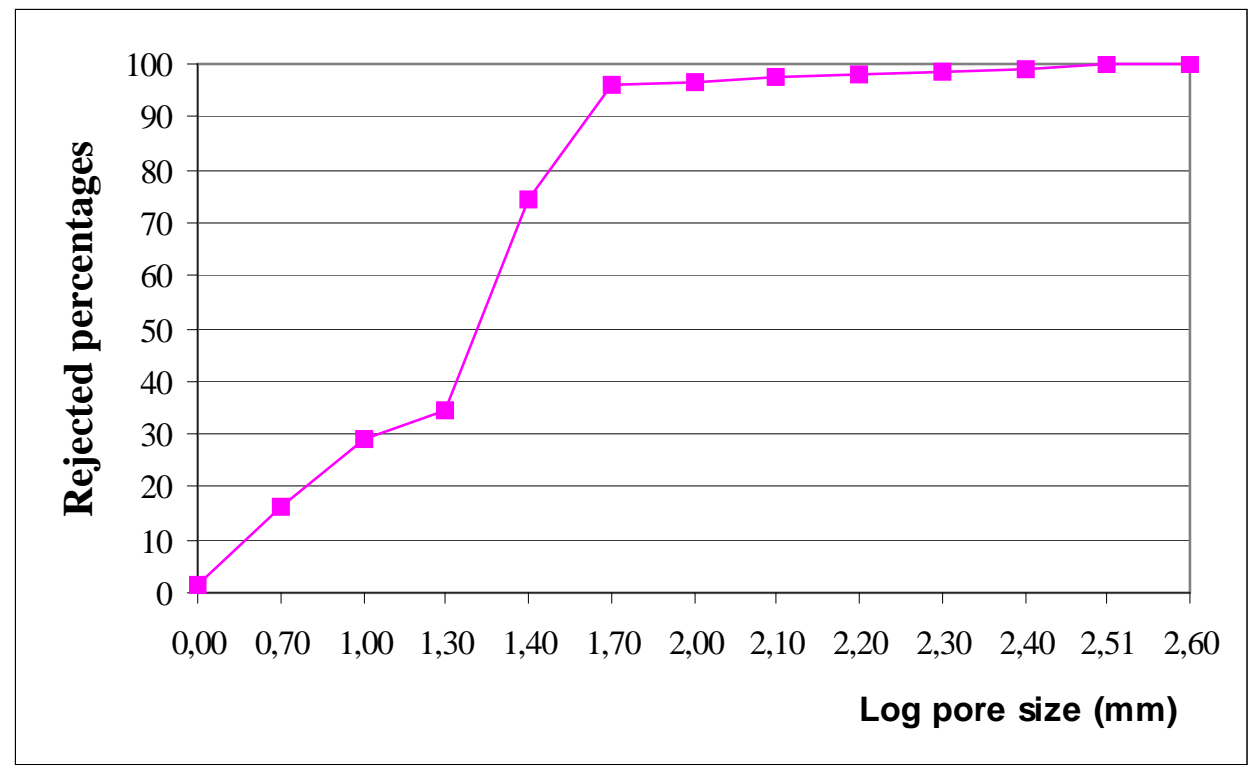

Figure 4. Granulometric curve MC1.

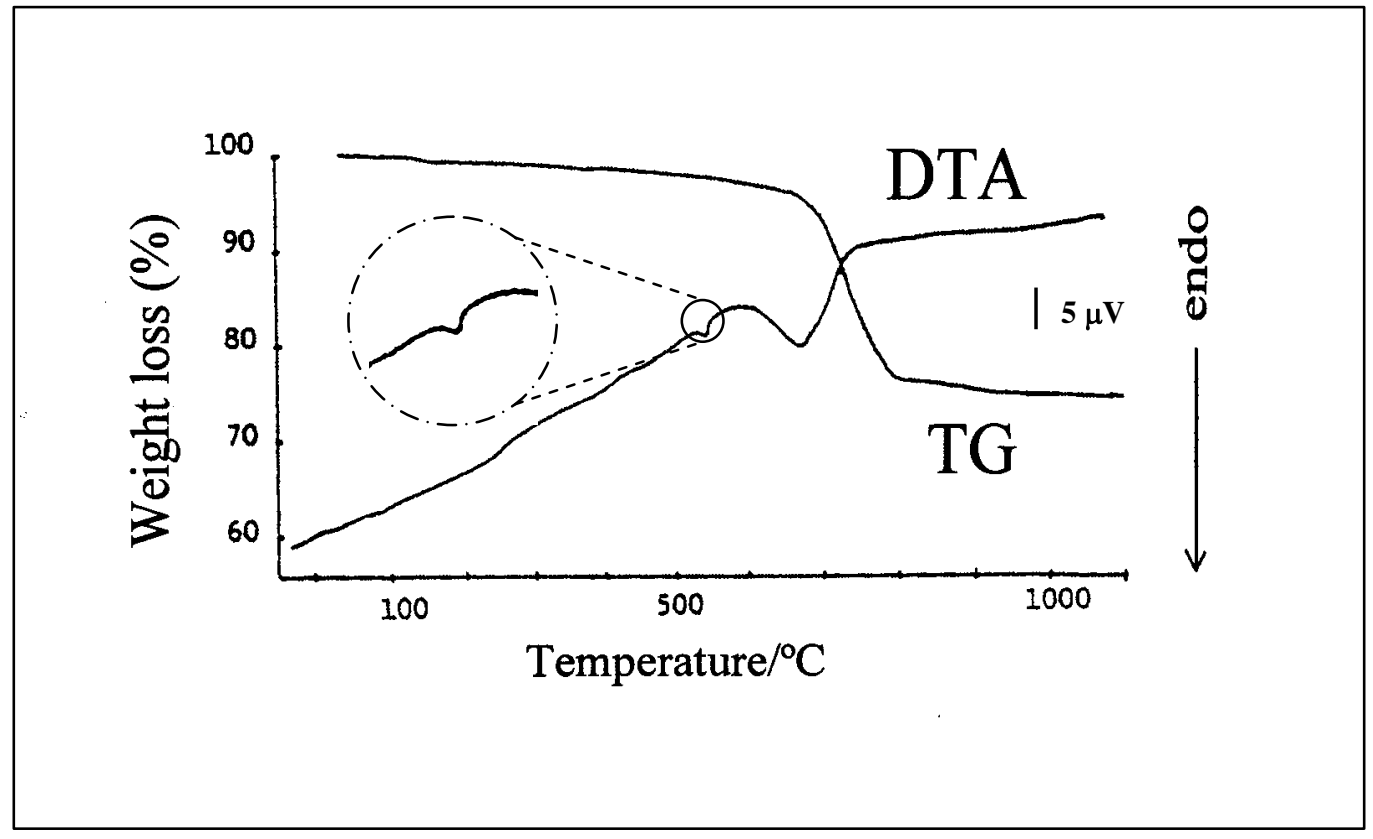

Figure 5. DTA and TG curves from MC1 mortar. 


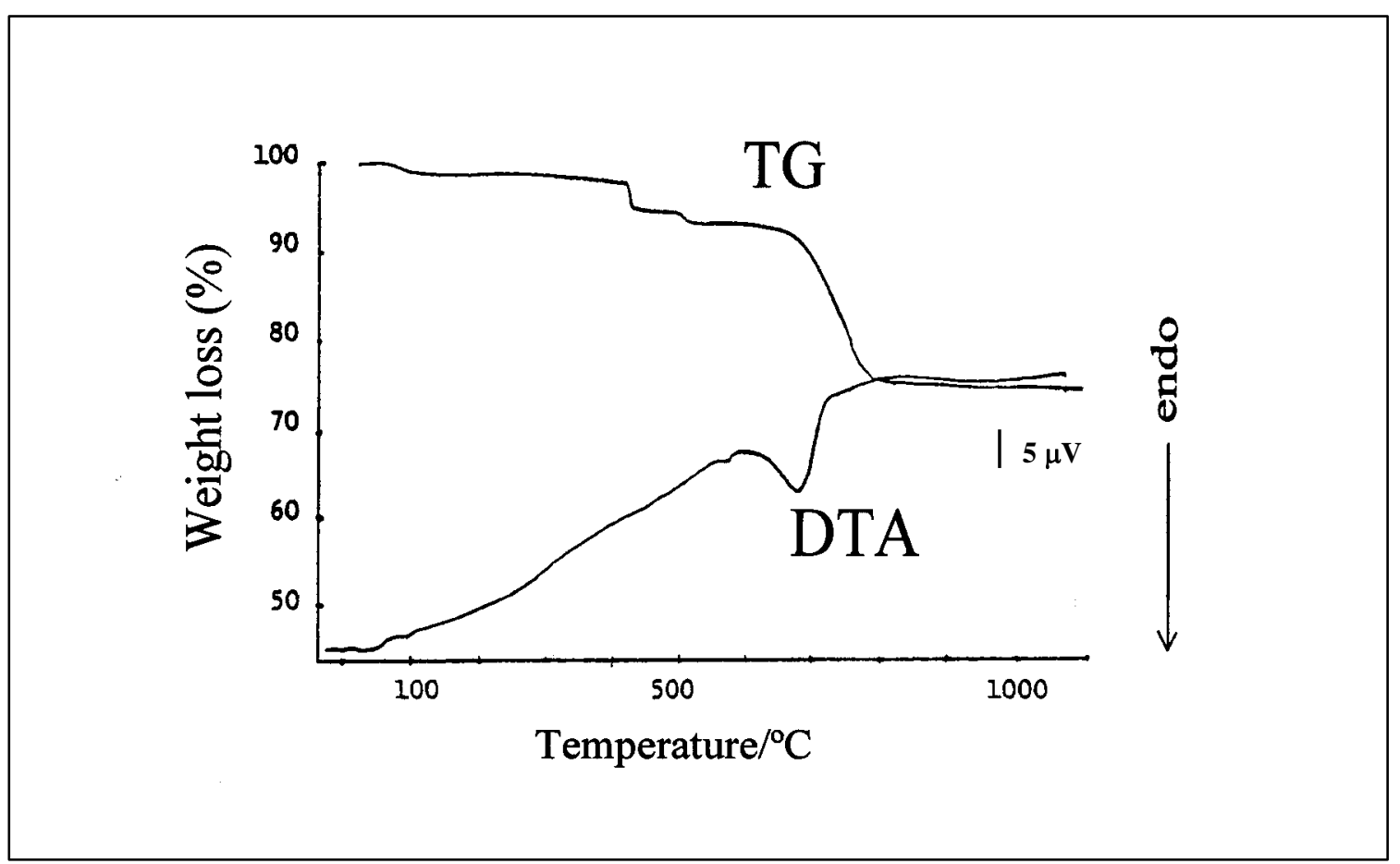

Figure 6. DTA and TG curves from MC6 mortar 